\title{
Exploring the Metabolic Rift: An Eco-Marxist Reading of Sam Shepard's The God of Hell
}

\author{
Amal Ibrahim Kamel *
}

One of the negative aspects of modern technology is the fact that we live in an age of environmental crises, resulting from man's eco-unfriendly practices that damage the livelihood on our planet. Grave ecological disasters such as shortage of drinking water or food supply, climate change, deforestation, depletion of natural resources, the extinction of some birds or animal species, global warming phenomenon, loss of biodiversity, contamination...etc. have become a major threat to man's life and well-being on earth. Ecocriticism is a movement that has started developing in the 1990s as a reaction to man's attitude to nature, highlighting frequent ecological disasters confronting the globe. As an interdisciplinary approach, ecocriticism is enriched by other fields of knowledge such as history, geography, environmental science, political science etc. It focuses on the dynamic relationship between man and nature in literary texts. According to William Rueckert (1978), (who first coined the term) in his seminal work, "Literature and Ecology: An Experiment in Ecocriticism", ecocriticism applies the ecological principles to the study of literature. According to Lawerence Buell, ecocriticism is "the study of the relationship between literature and the environment conducted in a spirit of commitment to environmentalist's praxis" (Buell 1995, 430).

As a term, eco-theatre refers to the intersection of ecology and performance. It aims at drawing the public's attention to the issues related to the environmental preoccupations as well as suggesting ways of conciliation between the human and the physical world. Being interpreted in a variety of ways since its publication in 2004, The God of Hell is treated as an outstanding text in Shepard's dramatic oeuvre. It has been frequently discussed as a political comment on the U.S. war in Iraq or Bush's war on terror. In her "There's Hell to Pay in Sam Shepard's Latest Play", Elysa Gardner praises the play as "pungent and poignant" and as "a powerful indictment of how our conduct toward prisoners abroad was influencing government behavior at home"

\footnotetext{
* Associate Professor of English Language and Literature, Faculty of Arts, Fayoum University.

Cairo Studies in English - 2020(2): https://cse.journals.ekb.eg/
} 
(Gardner 2004, 244). One of the previous reviews of the play entitled, "Effacing Myths and Mystification of Power: Sam Shepard's The God of Hell", written by Boróka Prohaszka Rad (2009), focuses on a reading of the play in the conceptual framework of Victor Turner's theories on ritual and liminality and Michel Foucault's "The Subject and Power". In a research paper entitled, "The Loss of National Identity in Sam Shepard's The God of Hell',Sahar Mokbel (2013) discusses the ways in which Shepard satirizes George Bush's administration and their policies after the 11 September, 2001 attacks. In Konstantinos Blatanis's study entitled "Mediating Acts of War/Staging Crises of Sensibility: David Rabe's Sticks and Bones, Eve Ensler's Necessary Targets, and Sam Shepard's The God of Hell", he focuses on three contemporary American dramatists and their attempts at offering innovative responses to moments of socio-political and cultural crises brought about by the Vietnam War, the Bosnia-Herzegovina War, and the war on terror, respectively (Blatanis 2008). Moreover, the play has also been approached from a social perspective as a commentary on the loss of national identity. A dissertation entitled "The Nightmare of the Nation: Sam Shepard and the Paradox of American Identity" written by Paul Seamus Madachy (2003) examines Shepard's conception of the American identity and its transformation. To the best of my knowledge, although there have been considerable critical studies of Shepard's The God of Hell, none to date has investigated the depiction of the natural world in the play, from an eco-Marxist perspective, paying attention to the significant relationship between man and the physical world.

The aim of this interdisciplinary study that binds drama with eco-Marxism is to examine the depletion of natural resources and the drastic transformation of the traditional American lifestyle caused by the capitalist system, in one of the most controversial plays by Sam Shepard. Eco-Marxism is a political belief system that combines the Marxist belief of anti-capitalism with ecology and proenvironment policies. This paper attempts to study Sam Shepard's The God of Hell using an eco-Marxist lens to reveal the effect of capitalist systems on man's physical well-being and the environment. The paper seeks to postulate that the play under study has two traits: the inseparability of environmental degradation and social oppression and the environmental activism that aims at saving the earth and its dwellers from annihilation. This paper argues that the play reveals the capitalist system's manipulation of violent mechanisms to subjugate both nature and man and that the exploitation of nature is exposed through physically and emotionally exploited humans. My argument is based on the hypothesis that the play works as an insightful discussion of the voluminous scale by which 
capitalists' pursuit of rapid profit alienates man from his environment with the aim of highlighting the socio-ecological rift and trying to restore social metabolism. In The God of Hell, the land has been centralized, eco-degradation is addressed, the need to create awareness on the sustenance of the ecosystem is stressed and the nature/culture binary opposition is deconstructed. The present research paper employs the methodology of eco-Marxism as a means of adopting an "earth-centered approach" (Glotfelty and Fromm 1996, xix) to the play selected for the study. The research tries to answer the following questions: what is the role played by capitalism in alienating man from his environment? To what extent has the capitalist system caused degradation to man and his natural surroundings? Through what methods have the capitalist power structures transformed traditional lifestyle in the countryside? The paper seeks to prove that the play under study highlights capitalist paradigms' responsibility for the socio-ecological predicaments, explores the interplay of the human and the natural world and investigates the urgent necessity to stop the threatening danger.

One of the aims of Ecocriticism is the deconstruction of nature/culture duality. It does not limit the world to the social realm, but it links the human world with the larger world that is "the entire ecosphere" (Glotfelty and Fromm 1996, xv-xxi). Ecocriticism engages itself in examining the representation of environment in literature from an interdisciplinary perspective that links literature to politics, science and morality (Clark 2001, 2-8). Moreover, ecocritics aim at subverting the discourse and the practices related to the ideology of anthropocentrism in favor of biocentrism that would replace man's abuse of nature with man's recognition of the value of nature. Gabriel Egan, a well- known ecocritic, points to the role played by the Industrial Revolution in the exploitation of the natural resources and in shaping the human attitude towards nature (Egan 2006, 22). He asserts that ecocriticism is concerned with "all that happens in literary culture that tends to create or sustain the political, social, and cultural conditions that ecopolitics seek to change" (34). This means that ecocriticism does not confine itself to reading works written about nature as it attempts to prove that ecological, social and political concerns are interrelated. Furthermore, ecocriticism pays attention to both social and environmental concerns by "developing insights of earlier critical movements, ecofeminists, social ecologists and environmental justice advocates" (Garrard 2004, 3).

In Land/ Scape/ Theatre, Chaudhuri and Fuchs have called for a new way of looking at nature and landscape in drama. Rather than regarding them as part of an external setting that serves the human who occupies the central position in the 
play, the nonhuman is given agency. This means that the converge away from anthropocentrism marks a transformation of the natural landscape into a living space; to "a way of seeing an ideologically and psychologically revealing statement about our relation to the world around us, to a way of not seeing, of masking and occluding the unsavory truths about our relations to each other and to the land we supposedly share" (Chaudhuri and Fuchs 2002, 1). Thus they have stressed the ecocritical significance of the play's setting through power and autonomy granted to it as part of the posthumanist approach.

According to David Pepper, Eco-Marxism is defined as "sociopolitical ideology that fuses the Marxist critique of capitalism with ecological issues and pro-environmental movements" (Pepper 1993, 23). Depending on the ecological Marxist writings of Karl Marx, and John Bellamy Foster, the research analyzes the devastating influence of the Capitalist policies on the ecosystem in Sam Shepard's The God of Hell. An Eco-Marxist reading of the play signals how capitalists' destructive political and economic structures are the origins of environmental deterioration and social injustice. In his Early Writings of Karl Marx, he points out:

Man lives from nature, i.e. nature is his body, and he must maintain a continuing dialogue with it if he is not to die. To say that man's physical and mental life is linked to nature simply means that nature is linked to itself, for man is a part of nature. (Marx 1975, 328)

In Marxist thought, much emphasis is placed on the idea that man and nature should be in harmony. Marxists harshly criticize capitalist systems as the root cause of man's alienation and earth's subjugation. Just as the capitalist regime exploits nature and its resources to the full extent through globalization and industrialization to accumulate wealth and acquire rapid profit, it also forcibly imposes servitude on the working class. One of the effects of globalization is trade liberalization and the flow of products and capital across borders. To maximize their profit, firms pressure governments to lower labor costs. Growth in international trade and the transfer of goods between importers and exporters have resulted in harmful transport related global emissions from fossil fuel use and oil spills that damage the natural environment.

Four key concepts, coined by Marx and used extensively by Bellamy Foster, a well-known ecological Marxist, are used in the analysis of Shepard's The God of Hell. These are: "Social Metabolism", "Metabolic rift", "Commodity Economy", and "Second Nature". The term "Social Metabolism" refers to "a 
process by which man, through his own actions, mediates, regulates and controls the metabolism between himself and nature" (Marx 2004, 554). It entails man's interaction with nature; an interaction that guarantees man's survival and nature's continuity. However, this interaction has already been interrupted by greedy capitalists who have paid much attention to economic considerations at the expense of the ecological considerations. Therefore, "Metabolic rift" or the callous destruction of the biosphere and the instability of man's relationship with nature have become the consequences of the exploitative capitalist policies and practices. These practices include, for instance, large-scale industry that results in pollution and energy consumption. Consequently, nature is completely abused by capitalism. Rubin Patterson points out that "the environment cannot sustain capitalism and capitalism certainly cannot sustain the environment" (Patterson 2010, 74). Several environmentalists focus on the contradiction between capitalists' practices and environmental social justice as the former work for the aspects of production and consumption for their own sake ignoring environmental sustainability.

"Commodity Economy" refers to the idea that laborers have been transformed into a commodity under the capitalist mode of production that fails to recognize their humanity. Synonymous with the manipulation of people, the exploitation of nature by means of coal, oil and natural gas depletion is one of the causes of "Metabolic Rift". The scarcity of raw materials and the separation of the farmers from nature have become the consequence. Foster maintains: "the greater capitalism's expansion, the more intense its ecological demands, and the greater the level of ecological destruction it imposes" (Foster 2000, 66).

Repairing the ecological rift has led capitalist forces to search for what Marx calls a "Second Nature". After destroying the ecology, capitalists have searched for alternatives for the devastated agricultural landscape to multiply their wealth. Their aim is to establish a profit-seeking economy regardless of ecological sustainability. For example, to fix the problems they have caused to the soil, capitalists have used artificial fertilizers that resulted in pollution. Accordingly, their second nature is hazardous too since it entails environmental crises elsewhere. Karen Bell argues:

Because the system requires constant growth, excessive natural resources are depleted and unsustainable levels of waste are created. Moreover, the derive for profit encourages cost cutting, putting pressure on corporations to choose the cheapest processes. Companies have to make short-term decisions based on what will 
help their business to survive, even if this harms society and the environment. (Bell 2015, 2)

The industrial capitalist system is largely criticized for its exploitation of people in the form of low wages and occasional work, and nature in the form of careless handling of waste products that cause disasters.

The illusion dominating the American conscience since 9/11 that America shall regain its previous uncorrupted rural environment once the 'enemy' is defeated, is challenged and satirized in The God of Hell. Shepard mourns the American culture's drastic transformation from the patriotic cowboy culture into a culture of paranoiac fear of an unidentifiable enemy. He synthesizes various verbal and non-verbal theatrical mechanisms such as the setting, structure, characterization, theme, stage directions, costume, stage props, music, lighting, stage symbols, pauses, silences, gestures, body language and startling visual images that contribute to the depiction of the amount in which capitalists' power structure has degraded nature and usurped power to make innocent individuals surrender.

\section{Social Metabolism}

A major tenet of Eco-Marxism is social metabolism; that is, human society interacts with nature and forms a self-reproducing system. Foster maintains that:

Marx avoided subordinating nature to society, or vice versa, allowing him to elude the pitfalls of both absolute idealism and mechanistic science. His metabolic analysis recognizes that humans and the rest of nature are in constant interaction, resulting in reciprocal influences, consequences, and dependencies. These processes emerge within a relational, thermodynamic whole, the universal metabolism of nature. (Foster and Clark 2020, 182)

In a mutual dynamic relation, human social systems interact with natural systems in the process of maintaining life. Unfortunately, transformations associated with capitalist system radically affect this relation. These transformations are reflected through the physical setting in The God of Hell as the shabby living room, the dimly lit rooms, the small kitchen with its "appliances dating from the fifties" (26), the "very loud, old-fashioned, crankstyle doorbell" (9), the "frosty windows" (3), the "distant vague, snowbound pastures" (5) and the old-fashioned mirrors all contribute to the feeling that the 
farmhouse is isolated and deserted by people. The mood of stillness that dominates the farmhouse as "nothing ever happens" (48) reflects the major changes in the twentieth century that have transformed American society. It is worth mentioning that in an idyllic setting, The God of Hell opens with a vivid picture of two archetypal Wisconsin farmers, Frank and Emma. The exposition in the dramatic structure sets the play's mood and portrays a decayed landscape. The set is a farmhouse, a traditional rural house with two sparcely furnished modest rooms separated by a kitchen counter, a small couch and a few chairs. It is more than a shelter since it represents the idea of belonging and the meaning of identity. The offstage is dimly lit. There is a "dim yellow light leaking up from stairs" (3) leading to the basement. The rural setting presented at the play's outset displays how environment is deeply involved in the farmers' daily activities.

In terms of structure, the play is written in one act, divided into three scenes, resembling vignettes; a division which displays condensation as well as fragmentation of our modern age. Through his protagonists, Frank and Emma, Shepard grieves over the inexorable decay of the agrarian community that has been invaded by big corporations. He dislikes the rising cities that outweigh rural landscape and he instead promotes dairy farms rather than supermarkets. In his dramatic portrayal of Frank's character, Shepard presents him as impotent to indicate that Frank is vulnerable and unable to secure his territory or his heifers from the intrusion of strangers. As a small scale producer, Frank carries out his duties with regard to his cows and his farm without complaint. He and his wife have real loyalty to their farmland. Shepard introduces his protagonists on stage in a manner that represents the traditional aspect of the American national persona. Manipulating body language as a powerful tool, the dramatist weaves the elements of nature with the protagonist's life as he depicts Frank sitting on the couch eating bacon and singing a traditional old song that keeps him warm after working in snowy weather.

Lights are on Emma when she enters and the stage directions describe her restless movement back and forth from the kitchen sink as she carries a plastic pitcher with water to her plants. "She waters plants and returns to refill pitcher, then repeats the process" (4). The exaggerated movement to the kitchen to bring water to her plants signals Emma's suspicion. Shepard uncovers the metabolic interaction between man and nature through Emma's character that always talks about the weather with Frank, cares for her plants and fries the bacon. The smell of bacon softens the apprehensive mood and it is highly associated with the nature of the countryside. Moments into the first scene, Frank and Emma are visited by Haynes, an intruder, who invades their little universe. Motivated by 
anxiety due to the current conditions in the dairy land, Emma says: "The door was open because this is Wisconsin and we all leave our doors open in Wisconsin! It's the open-door policy" (27-28). The dramatist depicts Wisconsin as a rural area where life is based on the connection between the farmers and the land. He refers to the past history where Americans used to fear nobody. The open door is associated with freedom, peace, and new possibilities.

The close interrelatedness of man and nature is revealed subtly through body language and its effective integration into the context of the performance. Subtext is essential here, where body language gives away a character's real intentions to the audience. For instance, the play offers an image of nurturing that leads to catastrophic ends. The image of Emma obsessively overwatering her houseplants is indicative of her interconnectedness with nature and symbolizes her yearning for children. Being emotionally involved with her plants, she cannot stop watering them. J.L. Styan points out "in the theatre an object or a situation can immediately suggest an idea or a feeling that is greater than itself" (Styan 1981, 3). Emma's plants, therefore, can be viewed as a stage prop manipulated to demonstrate that the plants resemble children who need her care. Sherylin MacGregor observes that “women's mothering and caregiving work mediates the relationship between people and nature and thereby engenders a caring stance towards nature. This rhetoric of 'ecomaternalism' is pervasive in much of the contemporary ecofeminist discourse" (MacGregor 2006, 4).

In scene two, one of the most significant examples of the use of body language is provided in the vivid portrayal of Emma's character watering her plants in a manner that entails an idealization of nature. Shepard depicts this scene in a way that foregrounds man's appreciation of land as a natural resource that needs cultivation. Emma is seldom still. She asserts, "If I didn't water like this, I wouldn't know what to do with myself. There would be a horrible gap. I might fall in" (20). Moreover, she complains that nobody farms anymore because of the government's policies and that the land has stopped being a productive place. Transformation in the dairy land is depicted through the image of Haynes' coffee stains on the sofa. The coffee spills now replace the blood of the birth of premature calves (48). Another example of the use of gestures and body language is provided in Haynes' repetitive staring out the window. Moving fast to a window and looking out reflects the extent to which he is threatened by danger. Moreover, whenever the doorbell is ringing, Haynes speaks to Emma in whispers because they are both afraid of Welch and they cannot speak out loudly. Haynes, suddenly, moves towards the basement stairs and disappears. Thus, the setting and the body language continue to echo the changes or the destructive 
effects that take place with the arrival of capitalism. It is worth mentioning that scene two ends with fading lights and a music interlude to provide the audience with relief after the tension created by Welch's torture of Haynes.

As a stage prop, Frank's heifers reveal the extent to which he is deeply attached to his dairy farm and nature. Animals constitute a part of the physical environment represented in the play. Una Chaudhuri maintains that "For Frank, his animals provide a rapture of participation in an agrarian world that is fast disappearing, taking with it the stability and certitudes once signified by the homestead, the ranch, the little house on the prairie" (Chaudhuri 2006, 52). She refers to the interrelatedness between the human and the animal sphere. Just like the green plants depicted at the play's outset reveal livelihood and man's association with nature, Frank's caring for his heifers indicates the animalhuman interconnectedness and biodiversity. As a term used extensively in ecological studies, 'biodiversity', i.e. "comprising animals, plants and microorganisms, their genetic variation and their organization into populations that assemble into ecosystems, is fundamental to the provision of ecosystem services" (Ierino 2010, 4). To highlight the intimate relationship between man and earth, Frank asserts, "We lead a very peaceful life here. We're in the country. We're dairy farmers" (19). The protagonists' commitment to their land and their connection to nature is a basic theme in the play since their human identity is intertwined with the ideal biosphere. Foster points out that, "human society exists within the earthly metabolism, continually interacting with its external natural environment in the production of goods, services, and needs. As a result, the social metabolism operates within the larger universal metabolism" (Foster and Clark 2020, 182).

Through the course of the play's events we find that both Frank and Emma fill their life with a certain obsession that controls their thoughts and behavior. While Frank is obsessed with his heifers since he always feeds them, Emma is obsessed with her plants. Both of them live in identification with nature. Shepard sheds light on the coexistence between humans and nature since Emma and Frank converse about nature and their dialogues reflect their respective fixations. As a nostalgic dramatist, Shepard yearns for the old days where Americans used to trust everybody and fear nothing. However, contemporary American society has transformed and has become dominated by paranoia. Suspicious and frightened, Emma asks various questions regarding the guest's origin, job and identity. Emma's dramatic portrayal is contrasted to Frank's since she has an innate female sense of danger and a questioning mind that keeps seeking truth whereas Frank's carelessness and apathy are stressed throughout the whole play. 
His ignorance makes his submission to Welch easy since he is not aware of this danger. The play creates an atmosphere of apprehension as well as nostalgia.

\section{Metabolic Rift}

Marx's theory of metabolic rift is based on the insight that capitalism causes an existential crisis in the human relation to nature. The concept refers to the "irrevocable rift in the interdependent process of social metabolism, a metabolism prescribed by the natural laws of life itself" (Marx 2004, 949). The irreparable rift in social metabolism is thoroughly tackled in The God of Hell. The play's theme focuses on an ecological crisis created by capitalism, namely the environmental issue of contamination by Plutonium that threatens the global ecosystem due to America's nuclear experiments. The action unveils that Haynes comes to the farmhouse to escape the oppressive forces of the American authority threatening him as he refuses to mend a nuclear leakage in Rocky Flats near Denver. The researches on plutonium were part of a national American project in Colorado. He exclaims, "I'm not going back there! The whole state is going to be blown off the map" (68). Haynes is followed by Welch, a secret agent of the American government, who represents another intruder in the farmhouse. The stage directions describe how he looks: "dark suit with American flag pin in his lapel, short cropped hair, crisp white shirt, red tie, attaché case in one hand and the cookie in the other" (10). Welch seems to be a mysterious dramatic character in the play as he says: "I'm not really allowed to reveal my affiliations exactly" (16). At the beginning, he assumes the identity of a salesman who sells American-made cookies and American flags. He tries to force Emma to buy a 'patriotic souvenir' from him to prove her patriotism. Thus, "flags" are used as a sign of loyalty and strong attachment to one's country. In his review of the play, Ben Brantley maintains that the "American ideal has shrunk into a more material form: a small, rectangular cookie frosted in stars and stripes of red, white and blue" (Brantley 2004, 1).

Moreover, stage directions describe Emma's reaction to his intrusion as she "stands still in semi-shock" (13). Shepard manipulates pauses and silences in Emma's dialogues with Welch to reflect the difficulty of having communication with him. His presence in the play intensifies the symbolic dimension for he represents American capitalism apparently delivering goods, but selling the American dream and trading on people's lives. He disrupts the harmonious relationship between the farmers and their land. Used as a symbol in the play, Welch stands for a capitalist who supports a free market economy rather than collective good. The dramatist sketches the conflict between the hegemonic 
practices of capitalism and the natural resources from the incentive moment of Welch's appearance in the play as he practices acts of slow violence that negatively affect plants, animals and humans. Foster maintains, "For Marx, the narrow pursuit of value-based accumulation, through the "robbery" of the earth itself, at the expense of eternal natural necessity, generated a metabolic rift in the relation between human society and the larger natural world of which it was an emergent part" (Foster and Clark 2020,192). Marx here points to the means by which capitalists plunder the natural resources of the earth and violate the social metabolism.

Disrupting the quietness of the natural and social order in the farm, Welch tells Emma that her farmhouse has been chosen to be a suitable place where they can apply a new policy. This alludes to the capitalist policy that works for the replacement of small-scale family farms by large enterprise investment in nuclear power and business. In other words, it marks the shift from an economy of production to commerce. As a creeper, Welch's appearance endangers the land and the lives of its inhabitants. Just as capitalists deal with the land as their private property, Welch makes full exploitation of the farmland plundering its resources. In his Capital, Marx rightly contends:

All progress in capitalist agriculture is a progress in the art, not only of robbing the worker, but of robbing the soil.... Capitalist production, therefore, only develops the techniques and the degree of combination of the social process of production by simultaneously undermining the original sources of all wealth - the soil and the worker. (Marx 2004, 637)

In the aforementioned quote, Marx scoffs at capitalism for robbing labor and nature and disturbing their metabolic interaction. For capitalists, material wealth is promoted rather than natural and social wealth. The American flags that Welch hangs all around Frank's house work as stage images by which Shepard attacks the American capitalist policy that has a superficial sense of nationalism. Shepard points to the idea that through violent mechanisms, capitalist policies have destroyed both nature and people's livelihood. He sharply criticizes American capitalism since it poses threats to the people and aims at accumulating money. Since his arrival at the farm, Welch violently attempts a transformation of the inhabitants' lifestyle. After Welch's exit, we find Emma ringing the bell to call for her husband. As a stage prop, the bell will be used again at the play's end to highlight her resistance to Welch. 
The characters in this nature-oriented play can be categorized into two groups: those who have ecological awareness and care about nature and its rights represented by Emma and Frank (before the transformation), and those who don't care about ecological justice and rights represented by Welch. As for Haynes, his existence in the farmhouse constitutes a menace to the environment and the people as his fingers emanate "blue flashes" whenever he touches anything due to Plutonium contamination. Haynes tells Emma that this happens due to a static shock. At the end of scene one, Haynes confesses to the couple the fact that he has been contaminated in a nuclear accident. He further explains to them the nature of Plutonium: "The most carcinogenic substance known to man. It causes mutations in the genes of the reproductive cells. The eggs and the sperm. Major mutations. A kind of random compulsory genetic engineering that goes on and on and on and on" (41-4).

Shepard denounces America's capitalist policy that invests in nuclear power. It invests money in destructive radioactive chemical compounds and nuclear weapons to gain profit at the expense of the earth and its dwellers. Since the natural realm and the human realm are inseparable, any eco-hostile activities would upset both the natural and the social orders. According to Costanza, "Ecosystem services are the benefits provided to humans through the transformation of resources (or environmental assets, including land, water, vegetation and atmosphere) into a flow of essential goods and services e.g. clean air, water and food" (Costanza et al. 1997, 253). The dramatist sheds light on both earthly and human catastrophic destruction as a result of fatal radiation produced by Plutonium. The play's title refers to Pluto or the god of the underworld in classical mythology. As the title indicates, like Plutonium, Welch represents the "god" of hell who, as a capitalist, seizes any opportunity to commodify both nature and man. Capitalist rulers have worked on the manipulation of nuclear power in reducing electricity costs and progressively increasing their profits, regardless of the hazardous risks their developed technology pose on the environment and the lives of thousands of farmers and workers who were killed or maimed. Unfortunately, the structures of production are transformed by capitalists into forces of destruction. Rays and particles coming out of radiation have caused cancer and birth defects at higher rates even in later generations. Serious genetic damage has also been caused to the living tissues since they are deformedly reproduced. A close reading of the scene suggests that Haynes' description of Plutonium as a 'tasteless, odorless and invisible" (18) deadly substance that causes total annihilation and environmental 
devastation parallels the catastrophic degradation of nature and the deterioration of soil conditions caused by capitalist commodity production. Foster argues:

Farmers not only desired, but were required by the sanctions of the market, to extract more from the soil in each successive cycle of production, on pain of economic failure. This meant that a metabolic rift, caused by the intensive robbing of soil nutrients and a boomand-bust cycle, was built into industrial-capitalist agriculture. (Foster and Clark 2020, 111)

Thus, farmers were obliged to speed up production to satisfy the capitalist market at the expense of the soil's fertility. Because deadly radioactive wastes have irremediable dangers, nature and man's safety are challenged. Furthermore, Frank and Haynes' conversation moves to a universal stance where the personal and the public overlap. Frank: "Are we talking about a world situation or something personal, Greig?" Haynes: "What's the difference?" (19). Thus, the play calls for an end to the eco-degradation since we live in one universe. Shepard strikes the audience's attention to the necessity of restoring a viable socio-ecological metabolism.

\section{Commodity Economy}

Nature's metabolic rift caused by the ramifications of capitalist policy has affected human metabolism as well. Marx argues that the exploitation of nature involves an expropriation of human bodily existence. He refers to the numerous ways by which substantial numbers of peasants are forcibly removed from the village, thus, squandering soil's vitality (Marx 2004, 182). In The Robbery of Nature: Capitalism and the Ecological Rift, Foster describes the conditions of workers:

Violence and coercion were integral components of the bonded labor system: confinement, flogging, beating, and rape were commonplace. In this living nightmare, slaves were beasts of burden, regularly deprived of the conditions that allowed for adequate sustenance. Escaped slaves were hunted, tortured, and killed, so long as there was a steady supply of more bonded workers. (Foster and Clark 2020, 21) 
Foster here exposes the exploitative nature of capitalism since the bodily metabolism of workers is violated by greedy capitalists. Moreover, Marx points out that capitalist production "squanders human beings, living labor, more readily than does any other mode of production, squandering not only flesh and blood, but nerves and brain as well" (Marx 2004, 182). Shepard unveils that under the hegemony of capitalism, man has become a commodity. In scene two, the audience is shocked by Frank's enslavement and his blind belief in the decisions of the American capitalist system represented by Welch. Frank's conversion becomes lucid through his following speech to Emma: "He's (Welch's) from the government... our government... That means he knows more than us. He's smarter than us. He knows the big picture... The Enemy" (35). Shepard exposes the process of Frank's brainwashing as Welch manages to convince him that Haynes is the identified "enemy". Alienated from his farmland, Frank now perceives Haynes as the "dangerous other" (31) who seems to be the messenger of a horrible god, sent to deceive him and pollute his living area. He even insults him verbally by calling him a "traitor" and "a pretender" (36). Welch attacks him claiming:

You're contaminated. You're a carrier. What're we going to do about that? We can't have you free-ranging all over the American countryside like some kind of heedless chicken, can we? You've already endangered the lives of your friends here, not to mention the Midwest at large. Now, that was pretty selfish of you, wasn't it? Poisoning the Heartland? (30)

Using visual images as well as live action, Shepard depicts two levels of visual reality, thus, interpolating the torture used by tyrannical landowners against dissenters who oppose their ideology. As a means of exercising his tyrannical power, Welch exposes both Frank and Haynes to electric shocks. The development of the scene shows that they have become two helpless tortured creatures unable to resist tyranny. Haynes is "now in T-shirt, bare feet, and old khaki pants" (90). Stage directions describe him as wearing "a black hood on his head" and a "cord runs directly into the fly of his pants" (90). The audience witnesses how Haynes is hooded and wired like war prisoners. He is subjected to humiliation, cruelty and debasement. Welch says: "It's just like holding the leash of a well-behaved dog" (90). Moreover, Welch continues his assault in an attempt to force Frank and Haynes to surrender. He even applies electric shocks to their genitalia. The audience witnesses some physical violence. The whole 
scene acts as a quasi-Beckettian microcosm reminiscent of Pozzo's and Lucky's relationship in Beckett's Waiting for Godot.

The play clearly illustrates that through Welch's character as a symbol, the cycle of ecological rift will never stop. The playwright here patently highlights how capitalist policies have invaded and destroyed America's farmlands and subjected its citizens to humiliation for the sake of capital accumulation. As Marx puts it, the emerging "bourgeois order was a vampire that sucks out its small-landholding feudal peasants' blood and brains and throws them into the alchemistic cauldron of capital" (Marx 2004,128). Just as the bourgeois exploits and enslaves the proletariat, Welch objectifies Frank and Haynes. In addition, he assumes the master's position claiming: "We can do whatever we want... We're in the driver's seat... We're in absolute command now" (70). In this sense, Welch stands out as a symbol that represents capitalists who act as owners of the entire globe. Moreover, Welch explains to Haynes earlier that he wants him in "a brand-new mission" (68). But Haynes understands the nature of this mission, i.e. fixing a nuclear leakage, where "the ground caught fire for thirty days! Not trees, not bush, but the raw earth!" (69). Welch carelessly responds, "We're doing nature a favor... We're provoking rebirth! (69). Welch considers Haynes as a wage laborer who has no control over his life. Shepard thus unmasks the capitalist government's power abuse and cruelty that "absorbs nature more fully and completely" (Smith 2007, 26). Accordingly, the dramatist lambasts the capitalist political ecology for systematically degrading nature and for usurping the power to manipulate innocent people.

The three-scene play is a critique of the hegemonic practices of the capitalist system that have changed the landscape and led to catastrophic outcomes in relation to human and non-human aspects of life. As the play progresses, the transformation of Frank's character takes place in scene three as he quits his job. Costume operates a signifying system in this scene. Frank wears a blue suit and a tie and carries an attaché case. The change of appearance unmasks another inward change. Costume delineates that he now rejects his former lifestyle and seems to be at odds with his own natural surroundings. He even sells his heifers for a good price in a manner that proves capitalist exploitation of animal species. This act symbolizes losing his deep-rooted connectedness with the land and yielding to the capitalist ways of gaining profit. It refers to what Marx calls, in his Early Writings, the "degradation" of animal species under capitalism (Marx 1975, 239). With Frank's heifers being sold, the symbol of a prosperous productive future for America is amputated. Foster points out, "Marx was acutely aware of the ecological conditions of animals and of the destruction and 
pollution wrought on them by capitalism" (Foster and Clark 2020, 121). Marx objects to the operations of the capitalist system and the methods used in increasing animals' production of meat and dairy that resulted in animal bodies' deformity, suffering and abuse. Parallels can be drawn between the separation of the worker from his means of production in Marxist thought and Frank's physical and spiritual alienation from his rural life. 'Commodity economy' is stressed here since farmers and laborers are transformed into a commodity under the corruptive capitalist system as they are subjugated into servitude. Furthermore, capitalists exploit plants and animals and radically alter their metabolic relations. As Marx puts it, "Cattle as draught animals are fixed capital; when being fattened for slaughter they are raw material that eventually passes into circulation as a product, and so not fixed but circulating capital" (Marx 2004, 241). For capitalists, the lives of cows are assessed merely in relation to production. They even regard pursuing energy as more essential than achieving environmental justice. Foster denounces the capitalist system because "external nature - water, air, living species - outside this system of exchange is viewed as a free gift to capital" (Foster and Clark 2020, 134). Thus, the capitalist system is attacked for being based on waste, destruction and deterioration of the natural conditions for the sake of capital accumulation.

As a defender of the traditional rural way of life, Emma tries to convince Frank to defy Welch and get his cows back. She voices her wrath: "This guy is taking over our house! He's taking over our whole life! (79). Moreover, Frank's fear becomes clear when he tells his wife that they are targeted and that "the plants, the milking parlor, the barn and the tractor will explode at any time" (81). The reference here is to the metabolic rift caused by nuclear explosion. Since the natural cycle has become imbalanced, nature will take revenge on those who abuse it. The tone intensifies the feelings of loss and uneasiness. Nevertheless, Emma uses visual gestures by using her potted plants as a shield to block the door in a faint attempt to save the remains of her pastoral rural life. The image of the door implies a further significance since Emma announces: "We are closing our doors to the outside world" (36). Thus, in contrast to "the open door policy' that Emma adopts in scene one, she now attempts to resist the assaults of capitalism by closing the door. This suggests that the earlier lifestyle of the selfsustaining American citizen has changed due to capitalist violent mechanisms.

The end of the play is emblematic since blue flashes come out not only from Haynes and Frank but also from Emma's plants that have become contaminated too. Emma's green plants that are supposed to be connected with life, growth and progress are now contaminated by Plutonium. Thus, Emma's physical, 
intellectual and psychological territories have been affected too by the oppressive practices of the capitalist power structure. Significantly, the setting continues to echo the hazardous consequences that have been caused by capitalistic intrusion with nature. The original natural characteristics of the setting have been changed by capitalists' power. The non-materialistic values of the villagers that were created by their peaceful co-existence with nature have been replaced by the competitive values of materialistic capitalism. With the arrival of capitalists to the pure and uncontaminated land, the deleterious effect of hegemonic centrism on the environment and the farmers emerges.

Stage directions provide the reader with a description of Frank and Haynes' march as "the two of them getting more and more in sync" and "they keep marching in unison" (96). Despite Emma's attempt to grab Frank's arm to stop him from marching with Haynes, he continues marching. The body language suggests that both Frank and Haynes are acting under the influential magic spell of the capitalist regime. To prove his loyalty and patriotism, Frank sacrifices his heifers and substitutes Wisconsin wilderness with Rocky Buttes. His mind has become fully saturated with wrong beliefs. This is symbolized in the form of blue light flashes that come from his body. The contamination of the land is accompanied by the subjugation of its dwellers. The environmental injustice is represented in a stunning image where the three of them walk in what seems to be a military march knocking down plants. Their step over the plants is an indication of the prodigious volume of destruction brought to nature. Moreover, the death of plants is a token of the death of the American values. Welch ordering Emma to "get these plants out of here" (96) is a symbol of his carelessness with regard to nature. The pathetic military march draws the audience's attention to the ways in which American capitalist policy has had a deleterious effect on the lives of its citizens. Furthermore, this image highlights the interconnection between capitalism and environmental devastation since it sheds light on the rift that has been created between man and nature. It, moreover, draws attention to the extent that capitalist economy is held responsible for the depletion of green areas since it is largely based on the exploitation of nature.

\section{Second Nature}

This refers to capitalists' invasion of new territories after devastating the agricultural landscape to further the accumulation of capital. Mészáros declares:

A basic contradiction of the capitalist system of control is that it cannot separate "advance" from destruction, nor "progress" from 
waste - however catastrophic the results. The more it unlocks the powers of productivity, the more it must unleash the powers of destruction; and the more it extends the volume of production, the more it must bury everything under mountains of suffocating waste. (Mészáros 1995, 174)

In the quotation, Mészáros points to the manifestations of the anti-ecological tendencies of capitalism no matter what sort of risk humanity will be confronted with. Ironically, instead of trying to restore a more integral relationship with nature, the grim reality is that capitalism's pursuit of capital accumulation through ruthless expansion has resulted in planetary rifts. Using no agit-prop shenanigans, Shepard hints at the government's adoption of capital policies that spend billions of dollars in using deadly nuclear weapons in a wider range, including launching nuclear attacks on other nations, regardless of the catastrophic outcomes such as landscape destruction and man's subjugation. The lifeless area itself where the protagonists will go represents capitalists' 'second nature' since it refers to deploying nuclear weapons and strategic warheads in other nations to the massive destruction of nature and suppression of the individuals. The image of decay is emphasized since nature has been destroyed and Frank is forced to be separated from his land and to leave his village to Rocky Buttes: "a different landscape. Wide open. Just like the wild wild West. Not a tree in sight. Endlessly flat and lifeless" (42). Significantly, Rocky Buttes symbolizes an environmentally-abused Western landscape. Defeated by Welch's brutal suppression, Haynes seems to adopt capitalistic attitudes and proceed with bomb-making. Shepard provides an explicit critique of the capitalist American policy that invades personal spaces and dehumanizes people. Paying no attention to bioenvironmental ethics, capitalists subjugate nature to their own needs since they do not respect it for its own intrinsic value. As Marx puts it, "Nature becomes purely an object for humankind, purely a matter of utility; ceases to be recognized as a power for itself' (qtd. in Foster, 2000, 148). So long as capitalists hold power, nuclear radiation will damage each and every living cell.

Through Frank and Haynes, Shepard stresses the parallelism between the devastation of nature and the humiliation of the American citizens but through the portrayal of Emma, he highlights women's place in the village. Emma is the only character who firmly resists the oppressive power of Welch; she is the only character who is not contaminated by Plutonium. Moreover, she represents the voice of harmony in the irreparably devastated agricultural environment. Emma's body language reveals that she is shocked since she walks extreme 
downstage and turns toward the audience staring out. Saddened and embittered, she keeps ringing a bell as a warning of the process of terrorizing American citizens, stripping them of their individuality and the destruction of the American rural idyll. The audience hears only the ringing of the bell since the music stops. Ringing the bell marks an alarm for the American government that relies heavily on destructive nuclear weapons ignoring the hazard of environmental issues; it marks a desperate call for an immediate response to save the earth from pressing ecological disasters. The dramatist manipulates lighting technique skillfully in his portrayal of this scene's end since lights fade and get dimmer while Emma's plants emanate blue flashes in an increasing intensity. Shepard's aim is to warn readers and audiences that the peoples of the world will be devastated if they don't stand together to protect their environment and resist injustice.

As the play draws towards a closure, the audience is stunned by Frank's ironic soliloquy that seems to be highly revealing:

It's times like this you remember the world was perfect once. Absolutely perfect. Powder blue skies. Hawks circling over the bottom fields. The rich smell of fresh-cut alfalfa laying in lazy wind rows. The gentle bawling of spring calves calling to their mothers. I miss the cold War so much. (39-40)

Soliloquy, as a verbal element manipulated in the framework of the play, marks a critique of the government's capitalist policies that divert resources from the real threat and spend record sums on 'modernizing' nuclear weapons and delivery systems in the cold war era. During the cold war the enemy was an external force but now the enemy is an insider. The elements of nature including "the blue skies", "the hawks", "the fields", "the wind", and "the calves", work as signs that connote peacefulness and tranquility. As indicated by the lines of the aforementioned quotation, Frank wants to be free like birds flying over fields, enjoying his freedom. Shepard alludes to the past when America used to be a utopian land of strength. However, the American capitalist system oppresses individuals in all places. It is, therefore, indirectly criticized for making America insecure and vulnerable to threats. The final direct address of Frank to the audience unmasks his yearning for "the world that was once perfect" (39) where freedom, ecological justice and human dignity were attainable. With this last speech, the play's message becomes crystal-clear: regaining natural order in the universe is deeply linked to reclaiming man's humanity. This message seems to be in harmony with the ecocritics' assertion that environmental problems can 
never be solved without paying attention to social injustice and oppression of the indigenous people. Thus, the playwright's exploration of the need for a healthy environment enables him to explore issues of political as well as social concerns. Land devastation, political corruption and human irrationality are intertwined in the fabric of the play.

Finally, analyzing Shepard's proto-environmental theatre through his thought-provoking play The God of Hell, has led one to explore the interrelation of the natural and the human worlds, their manipulation and abuse, in order to champion individual and collective eco-friendly programs to sustain and protect our planet. The dramatist has staged a catastrophic ecological problem, namely, Plutonium contamination, to dramatize the innumerable imprudent actions and cruelty of capitalist systems towards the environment and the common man. Through his eco-literary discourse, Shepard offers a harsh critique of capitalist practices through capturing the abuse of nature and the pathetic situation of man. Shepard aspires to achieve eco-friendly practices in a healthier environment. Moreover, he empowers women and dramatizes the need for resistance and rebellion. It is Emma who fearlessly resists transformation and who defiantly rings the bell in Shepard's play. A close reading of The God of Hell from an ecoMarxist perspective reflects Shepard's commitment to initiate a drastic social change through addressing the intertwined ecological and social issues in his community. His thematic preoccupation is relevant to the world at large and his protagonists embody the dilemma of the down-trodden everywhere. Obviously, by approaching grave ecological crises threatening the Earth as a habitable planet, Shepard warns us that it is due time for the whole world to work substantially for environmental justice, sustainable human development and for restoring the metabolic relation between nature and humanity.

\section{Works Cited}

Bell, Karen. 2015. "Can the Capitalist Economic System Deliver Environmental Justice?" Environmental Research Letters. vol.10, no. 12, (December):1-9.

Blatanis, Konstantinos. 2008. "Mediating Acts of War/Staging Crises of Sensibility: David Rabe's Sticks and Bones, Eve Ensler's Necessary Targets, and Sam Shepard's The God of Hell'".

$<$ http://ejournals.lib.auth.gr/gramma/article/view/6432/0>.

Brantley, Ben. 2004.That's No Girl Scout Selling Those Cookies. Theatre Review, The New York Times.

$<$ http://nytimes.com/2004/11/17/theater/reviews/17hell.html $>$. 
Buell, Lawerence. 1995. The Environmental Imagination: Thoreau, Nature Writing and the Formation of American Culture. London: Harvard University Press.

Chaudhuri, Una. 2006 "Hell in the Heartland: Mapping Post-Abou Gharib America in Sam Shepard's The God of Hell". In Space and Place in Contemporary Theatre and Drama; Papers Given on the Occasion of the Fourteenth Annual Conference of the German Society of Contemporary Theatre and Drama in English. Germany: Trier.

-----, and Elinor Fuchs. 2002. Land/Scape/Theater. USA: University of Michigan Press.

Clark, Timothy. 2001. The Cambridge Introduction to Literature and the Environment. UK: Cambridge UP.

Costanza, R. et al. 1997. The Value of the World's Ecosystem Services and Natural Capital. Nature, no. 387: 253-260.

Egan, Gabriel. 2006. Green Shakespeare: From Ecopolitics to Ecocriticism. London: Routledge.

Foster, John Bellamy. 2000. Marx's Ecology: Materialism and Nature. New York: Monthly Review Press.

-----, and Brett Clark. 2020. The Robbery of Nature: Capitalism and the Ecological Rift. New York: Monthly Review Press.

Gardner, Elysa. 2004. "There's Hell to Pay in Sam Shepard's Latest Play." Review of The God of Hell by Sam Shepard. USA Today, (17 Nov.), $<$ http://usatoday30.usatoday.com/life/theater/reviews/2004-11-16-god-ofhell_x.htm>.

Garrard, Greg. 2004. Ecocriticism. London: Routledge.

Glotfelty, Cheryll and Harold Fromm. 1996. The Ecocritical Reader: Landmarks in Literary Ecology. Athens: University of Georgia Press.

Ierino, Trevor J. 2010. "Biodiversity: The Engine Room of Ecosystem Services". Department of the Environment, Water, Heritage and the Arts. Ecosystem Services: Key Concepts and Applications. Australia: Canberra, no.1.

$<$ http://environment.gov.au/system/files/resources/db1aed45->.

MacGregor, S. 2006. Beyond Mothering Earth. Canada: University of British Colombia.

Madachy, Paul Seamus. 2003. "The Nightmare of the Nation: Sam Shepard and the Paradox of American Identity". PhD diss., University of Maryland. http://drum.lib.umd.edu/handle/1903/323

Marx, Karl. 2004. Capital: A Critique of Political Economy. Translated by Ben Fowkes. New York: Penguin Press. 
----- . 1975. Early Writings of Karl Marx. Translated by Gregor Benton. New York: Penguin Press.

Mészáros, István .1995. Beyond Capital. New York: Monthly Review Press.

Mokbel, Sahar. 2013. "The Loss of National Identity in Sam Shepard's The God of Hell". Global Advanced Research Journal of Arts and Humanities (GARJAH), Vol. 2, no.5, (October): 91- 95.

Patterson, Rubin. 2010. "A Great Dilemma Generates another Great Transformation: Incompatibility of Capitalism and Sustainable Environments". PGDT, vol. 9: 74-83. http://BRILL.org/10.1163/156914910x487924.

Pepper, David. 1993. Eco-Socialism: From Deep Ecology to Social Justice. London: Routledge.

Rad, Boróka Prohaszka. 2009. "Effacing Myths and Mystification of Power: Sam Shepard's The God of Hell". Philologica, vol. 1, no.1: 60-77.

Rueckert, William. 1978. "Literature and Ecology: An Experiment in Ecocriticism". Iowa Review, vol. 9, no. 1: 71-86.

Shepard, Sam. 2005. The God of Hell. New York: Vintage Books.

Smith, Neil. 2007. "Nature as an Accumulation Strategy" in Socialist Register, edited by L. Panitch \& C. Leys, The Merlin Press, vol. 43: 16-36. https://socialistregister.com/index.php/srv/article/view/5856.

Styan, J.L. 1981. Modern Drama in Theory and Practice: Symbolism, Surrealism and the Absurd. London: Cambridge U.P. 